\title{
ECC
}

\section{Creation of biodegradable polymeric materials with antimicrobial properties}

\section{Irina Kirsha,*, Olga Beznaeva ${ }^{b}$, Olga Bannikovab, Dmitry Myalenko ${ }^{b}$, Valentina Romanovac}

aDoctor of Chemical Sciences, Associate Professor. Moscow State University of Food Production 125080, Moscow, Volokolamskoye Highway, 11

${ }^{b}$ Candidate of Technical Sciences, Moscow State University of Food Production 125080, Moscow, Volokolamskoye Highway, 11

eMoscow State University of Food Production, 125080, Moscow, Volokolamskoye Highway, 11

Received: 06 July 2019, Accepted: 13 October 2019, Published: 01 November 2019

\begin{abstract}
In the current study, development of the polymer packaging modification technology with natural antimicrobial and antioxidant components were carried out. The aim was to add some new properties to the packaging in order to prolong the shelf life of packaged food products. The birch bark extract with the main active ingredient betulin and dihydroquercetin was used as the natural modifier. The natural starchbased fillers were used to impart the biodegradation effect on the polymeric materials. Definition of the rheological properties of polymers, deformation-strength characteristics of polymer compositions before and after the composting method, sanitary, and chemical properties of polymer materials were evaluated. It should be noted that the laboratory extruder with ultrasonic processing (US) of the polymer composite materials' melt (PCM) was used to obtain experimental samples. The results have proved the effectiveness of the usage of ultrasonic treatment to obtain PCM based on betulin and starch. A patent application was generated as well.
\end{abstract}

Keywords: Antimicrobial properties; betulin; biodegradable polymeric materials; starch; polymers; ultrasonic treatment.

\section{Introduction}

Constant expansion of the assortment of food products, as well as the general tendency to increase their shelf life, present special requirements for the packaging materials used. The chemical composition and structure of the packaging materials determine not only the safety of their use in contact with the product but also provide a set of required functional properties [1-3].
One of the significant problems is the suppression of the growth of undesirable surface microflora on food products. This problem can be solved by using certain stabilizing additives to products and the usage of aseptic packaging methods. A promising area is the usage of the so-called active packaging or smart packaging, which directionally affects the product [4-6].

*Corresponding author: Irina Kirsh

Tel: +7 (499) 7500111, Fax: N/A

Eurasian Chem. Commun., 2019, 595-603

E-mail: irina-kirsh@yandex.ru 
Currently, there are no packaging materials in the food industry that have antimicrobial antioxidant and other properties in relation to the packaged product, capable of stabilizing its safety indicators during storage, and also inhibiting the development of undesirable microflora on the surface of the package during its possible secondary seeding [7].

Therefore, as part of the work, it is appropriate to develop a technology for modifying polymer packaging with natural antimicrobial and antioxidant components, to implement fundamentally new properties of packaging materials. It is desirable to use birch bark extract with the main active ingredient - betulin, and dihydroquercetin as the natural modifier [7-11].

When creating packaging materials and polymer composite materials (PCM), the melting points of the components are of particular importance. They must not be lower than the melting temperature of the polymer; otherwise, their destruction is possible during the processing $[8,9]$.

The creation of biodegradable polymer materials is one of the promising areas in the field of recycling polymer waste $[12,13]$. Once in the environment, such materials are assimilated by microorganisms. The process of assimilation of polymer compositions proceeds in several stages, which are conditionally divided into hydrolysis, acetogenesis, and methanolysis. The susceptibility of polymeric materials is crucial for biofouling and biodegradation [14].

The ability of polymers to decompose and be absorbed by microorganisms depends on a number of characteristics, and the most important is the chemical nature of the polymer and its molecular weight $[12,14]$.

For the assimilation of polymers by soil microorganisms, there is the necessity for the preliminary splitting of long polymer macromolecules into shorter fragments, the molecular weight of which should be no more than 5000 [11]. In this case, it is considered that the polymer composition is subjected to bioerosion processes, followed by decomposition into low molecular weight components. These destruction processes can occur under the influence of factors of physical, chemical, or biological nature. For the utilization of synthetic polymers in vivo, functional additives, accelerating the destruction processes, are introduced into the polymers.

Many studies have been conducted on synthesis of the biodegradable polymer materials based on starch $[15,16]$. Starch has an extremely low price, which is made of agricultural products including, cereals, legumes, potatoes, and maize. The main advantage of these materials has become biodegradability while maintaining satisfactory physical and mechanical properties of polymer compositions during their operation period.

As a novel strategy, in the current study, it was tried is to create biodegradable polymeric materials with the antimicrobial properties using ultrasonic treatment.

The following tasks were set in this work:

- $\quad$ Conducting a comprehensive study of polymer compositions based on starch and antimicrobial additives.

- Investigating the physicochemical, rheological and physicomechanical properties of the compositions. 
- $\quad$ Studying the influence of the $\mathrm{BBE}$ on the properties of polymer compositions filled with starch;

- $\quad$ Studying the influence of the $\mathrm{BBE}$ on the properties of polymer compositions filled with starch.

\section{Methods}

The birch bark extract (BBE), selected as an antimicrobial additive, has all the necessary characteristics to be used in the process of high-temperature extrusion; since the BBE has a melting point $\left(240-260{ }^{\circ} \mathrm{C}\right)$, inert properties. This provides the opportunity to subject it to heat treatment without changing the original features.

Dihydroquercetin (DHQ) is a powder of pale yellow (cream) color, bitter in taste, with a woody smell and a mass fraction of moisture (up to $10 \%$ ). The melting point of the dihydroquercetin was $234-236{ }^{\circ} \mathrm{C}$.

Solubility of the dihydroquercetin in the aqueous-alcoholic medium increased from $0.1 \%$ to $18 \%$ as the proportion of alcohol increases from 30 to $90 \%$. In addition, dihydroquercetin exhibits good solubility in ethyl acetate. So, at the temperature of $20{ }^{\circ} \mathrm{C}$, the solubility of dihydroquercetin is about $1.9 \%$; at $40{ }^{\circ} \mathrm{C} \%$, at $70{ }^{\circ} \mathrm{C}-28 \%$. It is insoluble in non-polar solvents (Hexane, chloroform).

The main component of the extract is dihydroquercetin; its content in the substance is from 88 to $99 \%$. Depending on the purity of the product, dihydroquercetin may also contain other flavonoids. Also, the concentration of ECG with DHQ in polymer compositions was 0.5 and $1.0 \%$.
Corn starch with a particle size of $100 \mu \mathrm{m}$ with a share of fraction up to $30 \mu \mathrm{m}$ of at least $50 \%$ was used as a filler for biodegradable polymeric materials. The starch content in PCM was 20 and $40 \%$.

Low-pressure polyethylene brand 273-83 Kazanorgsintez was used as the polymer matrix.

The temperature range for the processing of polymer compositions in the zones of the laboratory extruder was 100-140 ${ }^{\circ} \mathrm{C}$. It should also be mentioned that the polymer compositions, obtained without ultrasonic treatment and additives, were used as control samples.

Organoleptic studies were carried out using visual inspection of the samples to determine the following characteristics of the material:

1) Color coating of the outer and inner layer;

2) Nature of the surface (bumps, roughness, etc.);

3) Presence of through holes, wrinkles, dirt, mechanical damage, fixed folds, and other defects.

The odor was evaluated using aqueous extracts. Following the requirements of the Technical Regulations, distilled water was used as the model solution.

A point scale, presented below in the form of Table 1, was used as the criterion for the assessment. 
Table 1. Odor intensity of water extracts

\begin{tabular}{ccc}
$\begin{array}{c}\text { Odor } \\
\text { characteristic }\end{array}$ & $\begin{array}{c}\text { The intensity of the } \\
\text { smell, score }\end{array}$ & The manifestation of smell \\
\hline $\begin{array}{c}\text { No smell } \\
\text { Very weak }\end{array}$ & 0 & There is no noticeable smell \\
Weak & 2 & The smell is not usually noticed but detected by an experienced taster \\
Noticeable & 3 & The smell is easily detectable and capable of causing negative feedback \\
Distinct & 4 & The smell easily attracts attention and causes a negative feeling \\
Very strong & 5 & The smell is obviously strong, causing a persistent negative feeling
\end{tabular}

Sanitary-hygienic studies of extracts from the developed samples were carried out on various model media.

When defining the quantitative migration of formaldehyde into extracts out of the developed samples, the calculation of its concentration according to the Equation 1 was used [14].

$X=\frac{100 \times q_{0} \times b \times 1000}{V_{a} \times V_{6}}$

Where $\boldsymbol{q}_{\mathbf{0}}$ is formaldehyde content, which is found according to the calibration curve (in milligrams), $b$ is coefficient taking into account the degree of conversion of formaldehyde, $\boldsymbol{V}_{\boldsymbol{a}}$ is conversion volume (in $\mathrm{cm}^{3}$ ), $\boldsymbol{V}_{\boldsymbol{b}}$ is water sample volume (in $\mathrm{cm}^{3}$ ).

The following research methods were utilized in this work:

- Definition of the rheological characteristics of the polymer. The rheological properties of the samples of polymer materials were evaluated using the capillary viscometry method, according to GOST 11645-86 "Plastics. Method for determining the melt flow rate of polymers". For conducting the experiment, an extrusion plastomer of the IIRT type was used.

- Definition of the physicomechanical properties of polymer compositions.

The studies were carried out in accordance with GOST 11262-80 "Plastics. Tensile Test Method". Samples tests were carried out on a tensile testing machine brand PM-50.

Samples were placed in containers with bio humus (TU 0391-111580962002) at the temperature of $23 \pm 2{ }^{\circ} \mathrm{C}$ and the humidity $60 \pm 5 \%$. The degree of biodegradation of PCM was determined by the change in physicomechanical properties during composting.

\section{Results and discussion}

The polymer compositions, based on starch and polyethylene (PE) were obtained. The amount of starch in the PE compositions was 20 and $40 \%$. The BBE with DHQ in PCM was added in the amount of 0.5 and $1 \%$. The obtained polymer composite materials (PCM) were explored in terms of the rheological, physicomechanical, and physicochemical properties (Table 2). 
Table 2. Values of the rheological, physicomechanical and physicochemical properties of PCM

\begin{tabular}{l|cccc}
\hline $\begin{array}{c}\text { The name of the PCM, (a method of } \\
\text { producing a polymer composite } \\
\text { with/without the use of US } \\
\text { treatment/number of fillers, \%) }\end{array}$ & $\begin{array}{c}\text { Pelt flow } \\
\text { rate (g/ } \\
\text { 10min) }\end{array}$ & $\begin{array}{c}\text { Breaking } \\
\text { stress MPa }\end{array}$ & $\begin{array}{c}\text { Elongation } \\
\text { at break, \% }\end{array}$ & $\begin{array}{c}\text { Water } \\
\text { absorption, \% }\end{array}$ \\
\hline PE, starch (without US /20) & 1,1 & 6,9 & 68 days) \\
PE, starch, (US/20) & 1,3 & 7,1 & 72 & 17 \\
PE, PCL, starch (US /20) & 1,3 & 6,5 & 60 & 19 \\
PE, starch (without US /40) & 0,6 & 3,6 & 4 & 18 \\
PE, starch (US/40) & 0,8 & 4,2 & 13 & 34 \\
PE, BBE, starch (US /40) & 0,8 & 4,4 & 10 & 47 \\
PE without filler without US treatment & 2 & 10 & 250 & 45 \\
PE without filler US & 2,5 & 8 & 350 & 0,1 \\
PE of electronic components the US & 1,3 & 10 & 220 & 0,8 \\
\hline
\end{tabular}

It can be concluded from the obtained results that the introduction of betulin had a minor effect on the physicomechanical properties of PCM. The introduction of starch was of great importance. In fact, the higher the starch content, the lower the deformation-strength characteristics.
It is seen that the ultrasonic treatment of PE compositions based on starch improved the physicomechanical properties and water absorption, which was a good indicator from the point of view of operational characteristics. Further studies were conducted by the composting method (Table 3 ).

Table 3. Change in elongation at break of polymer compositions after composting

\begin{tabular}{cc}
$\begin{array}{c}\text { Amount of starch in polymer compositions/number of } \\
\text { BBE/ method for producing PCM with/without the use of } \\
\text { US treatment }\end{array}$ & $\begin{array}{c}\text { Change in elongation at break of } \\
\text { polymer compositions after } \\
\text { composting, \% }\end{array}$ \\
\hline 20 / 0 / US & $32 \pm 2$ \\
20 / 1 / US & $30 \pm 2$ \\
20 / / without US & $20 \pm 2$ \\
40 / 0 / US & $52 \pm 5$ \\
40 / 1 / US & $48 \pm 5$ \\
$40 / 0 /$ without US & $34 \pm 3$ \\
PE/ without filler /US & $5 \pm 1$ \\
PE /without filler/ without the US & $2 \pm 1$ \\
PE /1 /BBE US & $2 \pm 1$
\end{tabular}

In the process of composting, starchbased polymer compositions lost their operational characteristics by $30-50 \%$, depending on the amount of starch in the compositions, and this indicator is about $10 \%$ higher for the samples 
obtained with the ultrasonic treatment of the melt. The introduction of the BBE into PCM has little effect on the elongation at break in the composting process.

At the next stage of the work, experimental samples of polymeric materials with antimicrobial additives were subjected to comprehensive tests on physicomechanical and physicochemical parameters in accordance with the requirements of the regulatory documents.

The conducted sanitary-hygienic studies showed that the modification of the polymer composition of the BBE in the concentration of $0.5-1.0 \%$ does not cause the migration of harmful substances in values exceeding the norms of maximum permissible levels of movement (Table 4).

Note. Composition of PCM: PE-78\%, starch - 20\%, BBE $-1 \%$.

Table 4. The results of sanitary-hygienic studies of extracts in various model media

\begin{tabular}{|c|c|c|c|c|c|c|}
\hline \multirow{3}{*}{$\begin{array}{l}\text { Name of the } \\
\text { indicator }\end{array}$} & \multirow{3}{*}{$\begin{array}{c}\text { Norm } \\
\text { accordin } \\
\text { g to } \mathrm{TR} \\
\mathrm{CU} \\
005 / 2011\end{array}$} & \multirow[b]{3}{*}{ ( \pm uncertainty) } & \multirow{2}{*}{\multicolumn{3}{|c|}{$\begin{array}{c}\text { Actual value } \\
\text { Exposure time ten days }\end{array}$}} & \multirow{3}{*}{$\begin{array}{c}\text { ND on } \\
\text { analysis } \\
\text { methods }\end{array}$} \\
\hline & & & & & & \\
\hline & & & $\begin{array}{c}\text { Citric acid } \\
2,0 \%\end{array}$ & $\begin{array}{c}\text { Lactic } \\
\text { acid } \\
3,0 \%\end{array}$ & $\begin{array}{c}\text { Lactic } \\
\text { acid } 0,3 \%\end{array}$ & \\
\hline 1 & 2 & 3 & 4 & 5 & 6 & 7 \\
\hline \multicolumn{7}{|c|}{ Safety indicator: } \\
\hline $\begin{array}{l}\text { Acetaldehyde, } \\
\mathrm{mg} / \mathrm{dm}^{3}\end{array}$ & $\begin{array}{l}\text { No more } \\
\text { than } 0,2\end{array}$ & $( \pm 18,8 \%)$ & $\begin{array}{l}\text { Less than } \\
0,05\end{array}$ & $\begin{array}{l}\text { Less than } \\
\quad 0,05\end{array}$ & $\begin{array}{l}\text { Less than } \\
\quad 0,05\end{array}$ & $\begin{array}{c}\text { MOOK } \\
4.1 .3166- \\
14\end{array}$ \\
\hline $\begin{array}{l}\text { Ethyl acetate, mg } \\
\qquad / \mathrm{dm}^{3}\end{array}$ & $\begin{array}{l}\text { No more } \\
\text { than } 0,1\end{array}$ & $( \pm 22,9 \%)$ & $\begin{array}{l}\text { Less than } \\
0,05\end{array}$ & $\begin{array}{l}\text { Less than } \\
\quad 0,05\end{array}$ & $\begin{array}{l}\text { Less than } \\
\quad 0,05\end{array}$ & $\begin{array}{c}\text { MOOK } \\
4.1 .3166- \\
14\end{array}$ \\
\hline Hexane, $\mathrm{mg} / \mathrm{dm}^{3}$ & $\begin{array}{l}\text { No more } \\
\text { than } 0,1\end{array}$ & $( \pm 18,4 \%)$ & $\begin{array}{l}\text { Less than } \\
0,005\end{array}$ & $\begin{array}{l}\text { Less than } \\
0,005\end{array}$ & $\begin{array}{l}\text { Less than } \\
0,005\end{array}$ & $\begin{array}{c}\text { MOOK } \\
4.1 .3166- \\
14\end{array}$ \\
\hline $\begin{array}{l}\text { Heptane, mg / } \\
\qquad \mathrm{dm}^{3}\end{array}$ & $\begin{array}{l}\text { No more } \\
\text { than } 0,1\end{array}$ & $( \pm 23,9 \%)$ & $\begin{array}{l}\text { Less than } \\
0,005\end{array}$ & $\begin{array}{l}\text { Less than } \\
0,005\end{array}$ & $\begin{array}{l}\text { Less than } \\
0,005\end{array}$ & $\begin{array}{c}\text { MOOK } \\
4.1 .3166- \\
14\end{array}$ \\
\hline $\begin{array}{l}\text { Acetone, mg / } \\
\mathrm{dm}^{3}\end{array}$ & $\begin{array}{l}\text { No more } \\
\text { than } 0,1\end{array}$ & $( \pm 16,6 \%)$ & $\begin{array}{l}\text { Less than } \\
0,05\end{array}$ & $\begin{array}{l}\text { Less than } \\
\quad 0,05\end{array}$ & $\begin{array}{l}\text { Less than } \\
\quad 0,05\end{array}$ & $\begin{array}{c}\text { MOOK } \\
4.1 .3166- \\
14\end{array}$ \\
\hline $\begin{array}{l}\text { Formaldehyde, } \\
\mathrm{mg} / \mathrm{dm}^{3}\end{array}$ & $\begin{array}{l}\text { No more } \\
\text { than } 0,1\end{array}$ & $( \pm 13,0 \%)$ & $\begin{array}{l}\text { Less than } \\
0,025\end{array}$ & $\begin{array}{l}\text { Less than } \\
0,025\end{array}$ & $\begin{array}{l}\text { Less than } \\
0,025\end{array}$ & $\begin{array}{c}\text { РД } \\
52.54 .492 \\
-2006\end{array}$ \\
\hline $\begin{array}{l}\text { Methyl alcohol, } \\
\mathrm{mg} / \mathrm{dm}^{3}\end{array}$ & $\begin{array}{l}\text { No more } \\
\text { than } 0,2\end{array}$ & $( \pm 14 \%)$ & 0,08 & 0,12 & 0,17 & $\begin{array}{c}\text { MOOK } \\
4.1 .3166- \\
14\end{array}$ \\
\hline $\begin{array}{l}\text { Butyl alcohol, mg } \\
\qquad / \mathrm{dm}^{3}\end{array}$ & $\begin{array}{l}\text { No more } \\
\text { than } 0,5\end{array}$ & $( \pm 20,8 \%)$ & $\begin{array}{l}\text { Less than } \\
0,05\end{array}$ & $\begin{array}{l}\text { Less than } \\
\quad 0,05\end{array}$ & $\begin{array}{l}\text { Less than } \\
\quad 0,05\end{array}$ & $\begin{array}{c}\text { MOOK } \\
4.1 .3166- \\
14\end{array}$ \\
\hline $\begin{array}{l}\text { Isobutyl alcohol, } \\
\text { mg / } \mathrm{dm}^{3}\end{array}$ & $\begin{array}{l}\text { No more } \\
\text { than } 0,5\end{array}$ & $( \pm 17,3 \%)$ & $\begin{array}{l}\text { Less than } \\
0,05\end{array}$ & $\begin{array}{l}\text { Less than } \\
0,05\end{array}$ & $\begin{array}{l}\text { Less than } \\
0,05\end{array}$ & $\begin{array}{c}\text { MOOK } \\
4.1 .3166- \\
14\end{array}$ \\
\hline $\begin{array}{l}\text { Propyl alcohol, } \\
\text { mg / } \mathrm{dm}^{3}\end{array}$ & $\begin{array}{l}\text { No more } \\
\text { than } 0,1\end{array}$ & $( \pm 17,2 \%)$ & $\begin{array}{l}\text { Less than } \\
\quad 0,05\end{array}$ & $\begin{array}{l}\text { Less than } \\
\quad 0,05\end{array}$ & $\begin{array}{l}\text { Less than } \\
\quad 0,05\end{array}$ & $\begin{array}{c}\text { MOOK } \\
4.1 .3166- \\
14\end{array}$ \\
\hline $\begin{array}{l}\text { Isopropyl } \\
\text { alcohol, } \mathrm{mg} / \mathrm{dm}^{3}\end{array}$ & $\begin{array}{l}\text { No more } \\
\text { than } 0,1\end{array}$ & $( \pm 16,7 \%)$ & $\begin{array}{l}\text { Less than } \\
0,05\end{array}$ & $\begin{array}{l}\text { Less than } \\
0,05\end{array}$ & $\begin{array}{l}\text { Less than } \\
0,05\end{array}$ & $\begin{array}{c}\text { MOOK } \\
4.1 .3166- \\
14\end{array}$ \\
\hline
\end{tabular}


The results also revealed that the absence of destructive processes in the received samples affected the quality and safety of the packaging. However, it should be noted that the increase in the migration of methyl alcohol was observed in the model medium of $3.0 \%$ lactic acid solution, although its value does not exceed permissible norms.

Next, the studies were conducted to determine the quantitative migration of the formaldehyde into the extracts from samples on various model media. The results are presented in Table 5.

Table 5. Formaldehyde content in various model media

\begin{tabular}{c|ccc}
\hline \multirow{2}{*}{$\mathbf{1}$} & \multicolumn{3}{c}{ Actual value } \\
\cline { 2 - 3 } & distilled water & $\begin{array}{c}\mathbf{0 . 3 \%} \text { lactic acid } \\
\text { solution }\end{array}$ & $\begin{array}{c}\mathbf{3 . 0 \%} \text { lactic acid } \\
\text { solution }\end{array}$ \\
\hline $\begin{array}{c}\text { The formaldehyde content in } \\
\text { polymer composite materials without } \\
\text { BBE, mg/dm3 }\end{array}$ & 0,025 & $\mathbf{3}$ & $\mathbf{4}$ \\
$\begin{array}{c}\text { Formaldehyde content in PCM with } \\
\text { BBE-0.5\%, mg / dm3 }\end{array}$ & 0,024 & 0,003 & 0,040 \\
$\begin{array}{c}\text { Formaldehyde content in PCM with } \\
\text { BBE-1.0\%, mg / dm3 }\end{array}$ & 0,012 & 0,007 & 0,022 \\
\hline
\end{tabular}

The research results showed that the concentration of formaldehyde in the model medium of $3.0 \%$ solution of lactic acid was higher than in the extracts based on distilled water.

The bacteria of the group Escherichia coli (BGEC), yeast, and mold fungi from the collection of the central laboratory of microbiology were selected as the objects of microorganisms in the microbiological studies.

The method of forced contamination was used - the surface of the packaging material was forcibly contaminated before the start of the study by BGCP at the concentration of $104 \mathrm{CFU} / \mathrm{cm} 3$, yeast at the concentration of $2.2 * 104$ $\mathrm{CFU} / \mathrm{cm}^{3}$ and molds at the concentration of $1.5 * 104 \mathrm{CFU} / \mathrm{cm} 3$ (Figure 2).

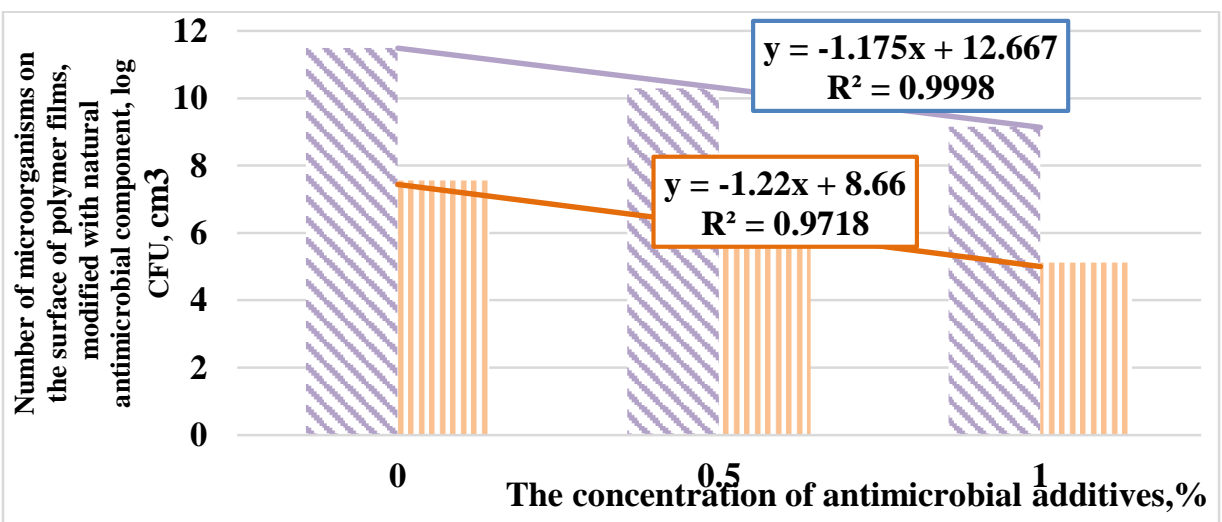

Figure 2. Change in the number of microorganisms of yeast and mold fungi in the washout from the surface of the polymer tape modified with natural antimicrobial components in various concentrations 
It was found that, the antimicrobial additive demonstrated the greatest antimicrobial effect on the BGKP and mold fungi and less on yeast. This may be due to the different resistance of microorganisms to extracts. Moreover, a similar effect was observed even with the minimal $(0.5 \%)$ injection of the extract into the PCM mass.

The obtained research results showed that the studied samples of the material had high antimicrobial efficiency in comparison with the selected microorganisms.

\section{Conclusion}

Comprehensive studies of model samples of polymer compositions based on starch and betulin were carried out:

1. All the obtained model samples complied with the regulatory documentation and the requirements of the technical regulation of the customs union «On packaging safety» TR TS 005/2011.

2. Extracts from the developed samples on various model media were investigated. It was observed that there is no migration of formaldehyde into the model medium; the obtained values do not exceed the values of DCM $\mathrm{mg} / \mathrm{L}$.

3. The results indicated that the polymer compositions lost their operational characteristics by $30-50 \%$ in the process of composting.

\section{Acknowledgements}

The study was supported by the Ministry of Education and Science of the Russian Federation.

\section{References}

[1] O.W. Lau, S.K. Wong, Journal of chromatography A, 2000, 882, 255270.

[2] V. Siracusa, P. Rocculi, S. Romani, M. Dalla Rosa, Trends in Food Science \& Technology 2008, 19, 634-643.
[3] A.M. Youssef, S.M. El-Sayed, Carbohydrate polymers, 2018, 193, 1927.

[4] I. Rowland, Proceedings of the Nutrition Society, 1981, 40, 67-74.

[5] D.S. Rao, A. Srivastava, Apple Academic Press, 2018, 273-292.

[6] K. Galić, M. Kurek, M. Ščetar, Meso: prvi hrvatski časopis o mesu 2019, 21, 338-346.

[7] K. Beloglazova, G. Rysmukhambetova, L. Karpunina, N. Konik, D. Ivanov, Research Journal of Pharmaceutical, Biological, and Chemical Sciences, 2019, 10, 747-752.

[8] I. Ali, D. Marenduzzo, J.M. Yeomans, The Journal of chemical physics, 2004, 121, 8635-8641.

[9] V.K. Thakur, M.K. Thakur, R.K. Gupta, International Journal of Polymer Analysis and Characterization, 2014, 19, 256-271.

[10] A. Singh, M. Kamal, Journal of Applied Polymer Science, 2012, 125, 1456-1459.

[11] B. Panea, G. Ripoll, J. González, A. Fernández-Cuello, P. Albertí, Journal of Food Engineering, 2014, 123, 104-112.

[12] N. Singh, R. Singh, I.P.S. Ahuja, Materials Today

Communications, 2018, 15, 124-127.

[13] S. Ali, A.A. Garforth, D.H. Harris, D.J. Rawlence, Y. Uemichi, Catalysis Today, 2012, 75, 247-255.

[14] W.J. Yang, K.G. Neoh, E.T. Kang, S.L.M. Teo, D. Rittschof, Progress in Polymer Science, 2014, 39, 1017-1042.

[15] D.R. Lu, C.M. Xiao, S.J. Xu, Express polymer letters, 2009, 3, 366375.

[16] E.K. Muluh, A.O. Ugbede, T.A. Tor-Anyin, Progress in Chemical and Biochemical Research, 2019, 2, 143149. 
How to cite this manuscript: Irina Kirsh, Olga Beznaeva, Olga Bannikova, Dmitry Myalenko, Valentina Romanova. "Creation of biodegradable polymeric materials with antimicrobial properties". Eurasian Chemical Communications, 2019, 595603. 